$<$ 原 著 $>$

急性ウイルス性重症肝炎における血清中 TNF- $\alpha$, 可溶性 TNF レセプターおよびICAM-1の動態とその臨床的意義 中舘一郎 阿部弘一滝川 康裕鈴木 一幸*

要 旨：急性ウイルス性肝炎における血清 TNF- $\alpha$, 可溶性 TNFレセプター（sTNFR）およ び可溶性 ICAM-1（sICAM-1）の動態とその臨床的意義について，とくに劇症肝炎などの重症 肝炎の病態との関連より検討した. 急性ウイルス性肝疾患においては血清 TNF- $\alpha$, sTNFR お よび sICAM-1の三者とも入院時には健常者に比較して有意の高値を示し, とくに sTNFR は劇 症肝炎急性型において最も高值で, 急性肝炎, 急性肝炎重症型に比しても有意であった。入院 後の経過では, TNF- $\alpha$, sTNFR, sICAM-1とも急性肝炎, 急性肝炎重症型では低下し, とく に sTNFR の低下は有意であった。一方, 劇症肝炎, LOHFでは, 死亡例の多くは TNF- $\alpha$, sTNFR とも高値で,ささらに上昇を示し, sICAM-1はほぼ全例で低下したが, 健常者に比して高 値であった，各種検査成績との関連では，TNF- $\alpha$ はGOT, GPT, FDP との間に, STNFR は GOT, GPT, PT, HPT, FDP, WBC, hHGF との間に, ICAM-1は T. Bil, PT, HPT, AT-III との間に有意の相関関係が認められた。 以上の成績より劇症肝炎などの重症肝炎において血清 TNF- $\alpha$, sTNFR, sICAM-1の測定はその病態把握に有用であり，とくに sTNFR が最も鋭敏 なマーカーになる可能性がある。

索引用語： 急性肝炎 劇症肝炎 TNF- $\alpha$ 可溶性 TNFレセプター ICAM-1

\section{はじめに}

ウイルス性肝炎においては, 肝障害の発生とその進 展に宿主の免疫応答が重視されている，とくに劇症肝 炎においては，活性化マクロファージより種々のサイ トカインが産生され，肝類洞内皮細胞障害による局所 の循環障害を惹起し肝細胞障害へと進展する機序が想 定され1),サイトカインの中ではとくに tumor necrosis factor- $\alpha$ (TNF- $\alpha$ ) p interleukin-1 (IL-1) の 役割が注目されているる2,3).最近, 血清中に可溶性 TNF 受容体 (soluble TNF receptor；以下sTNFR) の存 在することが明らかとなり ${ }^{4,5)}$, その生理学的作用を含 めた意義について検討されてきているがいまだ結論は 得られていない.

一方，免疫応答に際しては細胞間の情報伝達や免疫 担当細胞の作用発現に多くの細胞間接着因子が重要な 役割を果たしていることが明らかにされてきている が,これら細胞間接着因子については慢性肝障害にお
ける検討が中心であり，急性肝障害での検討は少ない.

そこで, 本研究では炎症性サイトカイン, とくに TNF- $\boldsymbol{\alpha}$ と STNFR おるよび細胞接着因子のひとつであ る intercellular adhesion molecule-1 (以下 ICAM-1) を血清レベルで測定し，急性ウイルス性肝疾患におけ る䠦床的意義を明らかにすることを目的とした。

\section{対象および方法}

\section{1. 対象}

急性肝炎15例 (以下 AH), 急性肝炎重症型 (AH で, 入院期間中にプロトロンビン時間が $40 \%$ 以下を示すも 昏睡II度以上の肝性脳症の発現を認めないもの：以下 AHS) 10例, 劇症肝炎急性型 (以下 FHA) 8 例, 劇症 肝炎亜急性型 (以下 FHS) 3 例, 達発性肝不全 (発症 より 8 週間以上 6 力月以内に肝性脳症の発現をみたも の: late onset hepatic failure; LOHF) 5 例の計 41 例および健常者 6 例を対象とした。

ウイルス学的な診断は, IgM-HA 抗体（RIA 法），

Ichiro NAKadate, Koichi ABE, Yasụhiro TAKIKawa and Kazuyuki SuzukI*

*岩手医科大学第 1 内科

<受付日1995年 6 月 12 日 $>$ 
Table 1 Background and clinical features of subjects.

\begin{tabular}{c|c|c|c|c|c|c|c|c|c|c|c|c}
\hline & no & age & gender & A & B & C & N & $\begin{array}{c}\text { T. Bil } \\
(\mathrm{mg} / \mathrm{d} l)\end{array}$ & GOT(IU/l) & GPT (IU/l) & PT (\%) & $\begin{array}{c}\text { Survival } \\
\text { rate(\%) }\end{array}$ \\
\hline control & 6 & $34.0 \pm 6.8$ & $6: 0$ & - & - & - & - & - & - & - & - & - \\
AH & 15 & $31.5 \pm 11.0$ & $6: 9$ & 4 & 5 & 2 & 4 & $5.8 \pm 6.4$ & $728 \pm 1,065$ & $1,258 \pm 1,154$ & $87.7 \pm 21.8$ & 100 \\
AHS & 10 & $37.3 \pm 12.8$ & $4: 6$ & 4 & 3 & 1 & 2 & $15.5 \pm 11.5$ & $2,862 \pm 3,653$ & $2,755 \pm 1,967$ & $52.5 \pm 22.1$ & 100 \\
FHA & 8 & $48.0 \pm 20.5$ & $1: 7$ & 1 & 2 & 0 & 5 & $10.2 \pm 5.6$ & $6,355 \pm 7,198$ & $5,252 \pm 4,639$ & $17.4 \pm 7.8$ & 37.5 \\
FHS & 3 & $60.7 \pm 10.4$ & $1: 2$ & 0 & 1 & 0 & 2 & $20.1 \pm 8.6$ & $561 \pm 380$ & $380 \pm 209$ & $28.2 \pm 13.1$ & 0 \\
LOHF & 5 & $56.2 \pm 17.3$ & $1: 4$ & 0 & 2 & 0 & 3 & $22.9 \pm 12.1$ & $301 \pm 240$ & $331 \pm 343$ & $45.6 \pm 17.6$ & 0 \\
\hline
\end{tabular}

AH : acute hepatitis, AHS : acute hepatitis severe form, FHA : fulminant hepatitis acute form, FHS : fulminant hepatitis subacute form, LOHF : late onset hepatic failure, A : IgM ant-HA positive, B : IgM anti-HBc positive or HBs Ag positive, $\mathrm{C}$ : anti $\mathrm{HCV}$ (2nd) positive or HCV RNA positive, $\mathrm{N}$ : negative for virus markers, $\mathrm{T}$. Bil : total bilirubin, GOT : gulutamic oxaloacetic transaminase, GPT : glutamic pyruvic transaminase, PT : prothrombin time.

HBs 抗原 (RIA 法), HBs 抗体 (RIA 法), IgM-HBc 抗体 (RIA 法)，第II世代 HCV 抗体 (EIA 法), HCVRNA (PCR 法)，およびEB ウイルス，サイトメガロ ウイルス関連マーカーの測定によって行った. A 型の 診断は IgM-HA 抗体陽性により, B 型の診断は IgM$\mathrm{HBc}$ 抗体陽性により行い, C 型の診断は, $\mathrm{AH}$ および AHSにおいては経過中に HCV 抗体が陽性化したも のを, FHA, FHS, LOHFにおいては, 治療前の初血 清において HCV-RNA が陽性を示した症例とした。 なお, 今回の検討では, FHA, FHS, LOHFにおいて は B 型肝炎ウイルスキャリアーからの発症例は除外 した。

各疾患群の背景因子および入院時の代表的な肝機能 検查值を Table 1 に示した. FHSおよび LOHFでは $\mathrm{AH}$ に比して有意に年齢が高く，また各群とも女性の 比率が高かった. 成因では AH および AHSでは A 型 と B 型の頻度が高かったが，他の疾患では B 型と非 $\mathrm{A}$ 非 $\mathrm{B}$ 非 C 型が大部分を占めた.

\section{2. 血清の採取および保存}

患者血清は, 入院時の無治療の状態のものと入院後 平均13.5土4.2日（5〜26日）のものを用いた。 なお血 清は分離後測定までー $20^{\circ} \mathrm{C} に て$ 保存した。

\section{3. サイトカインの測定}

各サイトカインの測定は以下の測定キットを用いて 行った. TNF- $\alpha$ : TNF ELISA (Endogen, USA) (ELISA), sICAM-1 : ICAM-1 Test kit (T cell diagnostics, USA) (ELISA), sTNFR-I and -II : Biotrak (Amersham life science, England)

\section{4. 統計学的検討}

各サイトカインの測定值は平均値士標準偏差で表示 し, 統計学的な検討には $\boldsymbol{\chi}^{2}$ 検定, 一元分散分析 (one- way Anova), Mann-Whitney のU 検定を用い, 危険 率 $5 \%$ 以下を有意として取り扱った。

\section{成 績}

\section{1. 血清 TNF- $\alpha$}

入院時の血清 TNF- $\alpha$ は健常者 $8.2 \pm 2.2(\mathrm{pg} / \mathrm{m} l)$, AH 25.4 \pm 22.9 , AHS 33.8 \pm 52.3 , FHA 40.9 \pm 37.5 , FHS $18.3 \pm 11.2$, LOHF $20.2 \pm 11.4$ であり, FHA, FHS およ゙ LOHF などの重症例において健常者より も有意 $(p<0.05)$ に高值を示した. AH とAHSにお いても健常者に比して高値をとる傾向が認められた が, 有意差は認められなかった（Fig. 1).

入院時と入院後との比較では, 各疾患群ともに有意 の変化は認めなかった. しかし, 個々の症例における 変動を検討すると, AH およびAHS では, ほほ全例が 入院後に低下を示した。一方, 劇症肝炎ではFHA 8 例 中 3 例, FHS 3 例中 2 例において入院後にさらに上昇 を示す例が認められ，これらは全例死亡例であった (Fig. 1, 2).

血清 TNF- $\alpha$ と肝機能検查値わよび血液凝固検查値 との相関を検討すると, Table 2 に示すように, T. Bil とは負の相関傾向, GOT, GPT, FDP とは有意の正の 相関，また STNFR との間には有意の正の相関が認め られた。

\section{2. 血清 $\mathbf{S T N F R}$}

血清 STNFRについては，55kDの sTNFR-I と75 $\mathrm{kD}$ のTNFR-II の両者を測定したが，著者らは既に これら $2 つ の \mathrm{sTNFR}$ が高い相関性を示し, 両者とも に各種肝機能検査值との相関関係が一致していること を報告している6゙.したがって本論文では $55 \mathrm{kD} の$ STNFR-Iについてのみ示した.

各疾患群における入院時の血清 STNFR は, 健常者 


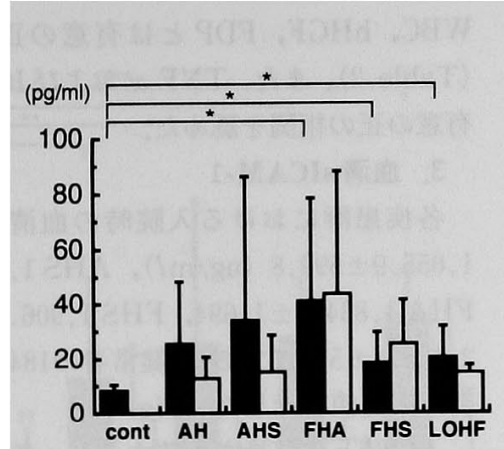

TNF- $\alpha$

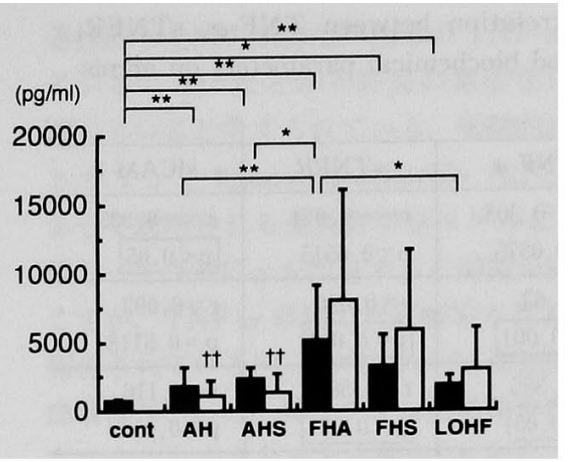

STNFR

Fig. 1 Serum levels of TNF- $\alpha$ and STNFR in patients with acute hepatitis on (ם) and after ( $\square$ ) admission. cont : healthy control, AH : acute hepatitis, AHS : acute hepatitis severe form, FHA : fulminant hepatitis acute form, FHS : fulminant hepatitis subacute form, LOHF : late onset hepatic failure. ${ }^{*}: \mathrm{p}<0.05,{ }^{* *}: \mathrm{p}<0.01$ compared with level of control. $\dagger+$ : $p<0.01$ compared with levels on admission.
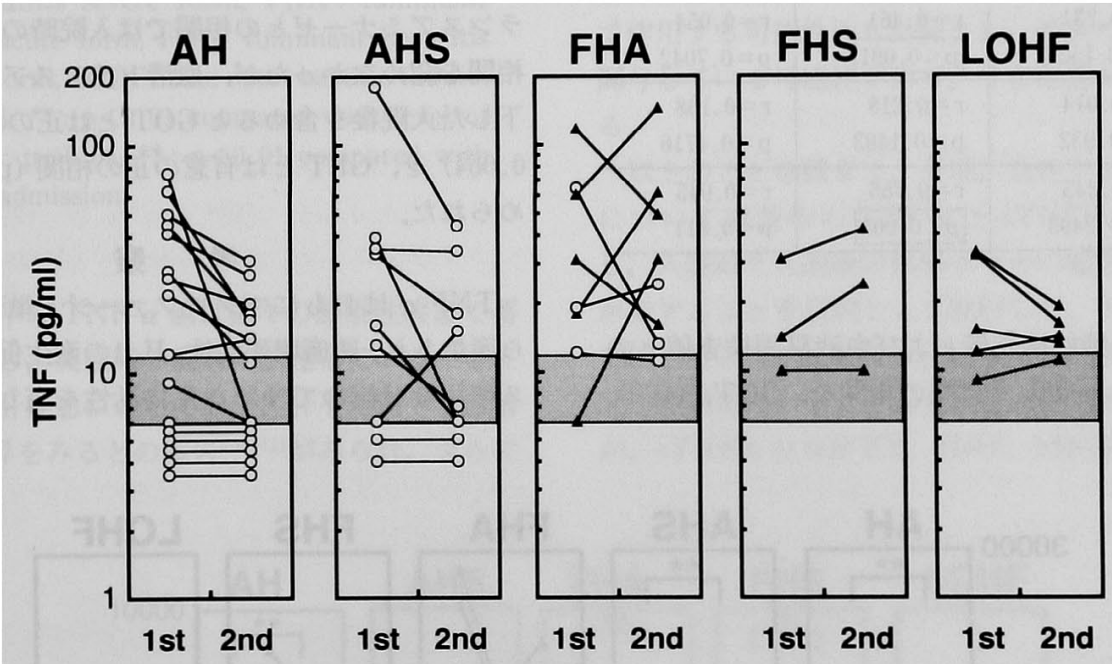

Fig. 2 Serial change in TNF- $\alpha$ levels in patients with acute hepatic diseases. O- $\mathrm{O}$ : survivor, $\mathbf{\Delta}-\mathbf{\Delta}$ : nonsurvivor, $\square$ : normal range, 1st : on admission, 2nd : after admission.

の752.7 $\pm 99.0(\mathrm{pg} / \mathrm{m} l)$ に比して有意に高值を示した。

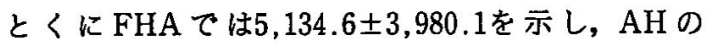
$1,788.5 \pm 1,446.3$, AHS $2,311.3 \pm 880.7$ よび LOHF の1,825.4 \pm 696.6 に比して有意に高値であっ た (各々 $\mathrm{p}<0.01, \mathrm{p}<0.05, \mathrm{p}<0.05)$ (Fig. 1).

入院時と入院後との比較では, AH およびAHSで は入院後に有意 $(p<0.01)$ な低下を示したが, 劇症肝 炎 (FHA，FHS) およびLOHFでは明らかな低下は 認められなかった. FHA 8 例中 3 例, FHS 3 例中 1
例，LOHF 5 例中 4 例ではむしろ上昇がみられ，これ らはいずれも死亡例であった（Fig. 3).

FHA, FHS およびLOHF などの重症例について生 死別に検討すると，入院時および入院後の STNFR は 生存例 ( 3 例) では各々 $4,312.3 \pm 3,042.0(\mathrm{pg} / \mathrm{m} l)$, $2,264.7 \pm 406.6$, 死亡例（12例）ては各々3,698.9土 $3,392.8,6,921.4 \pm 7,933.6$ あ゙あ，入院時および入院 後ともに生存例と死亡例の間に有意差は認められな かった。 
Table 2 Correlation between TNF- $\alpha$, STNFR, sICAM-1 and biochemical parameters on admission.

\begin{tabular}{|c|c|c|c|}
\hline & TNF- $\alpha$ & sTNFR & sICAM-1 \\
\hline T. Bil & $\begin{array}{l}\mathrm{r}=-0.303 \\
\mathrm{p}=0.0575\end{array}$ & $\begin{array}{l}r=-0.074 \\
p=0.6515\end{array}$ & $\begin{array}{l}r=-0.335 \\
p<0.05\end{array}$ \\
\hline GOT & $\begin{array}{l}r=0.63 \\
\mathrm{p}<0.001\end{array}$ & $\begin{array}{l}r=0.696 \\
p<0.001\end{array}$ & $\begin{array}{l}r=0.093 \\
p=0.5118\end{array}$ \\
\hline GPT & $\begin{array}{l}r=0.385 \\
p=0.05\end{array}$ & $\begin{array}{l}r=0.585 \\
p<0.001\end{array}$ & $\begin{array}{l}r=0.116 \\
p=0.4119\end{array}$ \\
\hline PT & $\begin{array}{l}\mathrm{r}=-0.182 \\
\mathrm{p}=0.2538\end{array}$ & $\begin{array}{l}r=-0.483 \\
p<0.001\end{array}$ & $\begin{array}{l}r=-0.344 \\
p<0.05\end{array}$ \\
\hline HPT & $\begin{array}{l}\mathrm{r}=-0.063 \\
\mathrm{p}=0.6993\end{array}$ & $\begin{array}{l}r=-0.483 \\
p<0.001\end{array}$ & $\begin{array}{l}r=-0.376 \\
p<0.01\end{array}$ \\
\hline AT-III & $\begin{array}{l}r=-0.046 \\
\mathrm{p}=0.8063\end{array}$ & $\begin{array}{l}r=-0.289 \\
p=0.1149\end{array}$ & $\begin{array}{l}r=-0.381 \\
p<0.05\end{array}$ \\
\hline FDP & $\begin{array}{l}r=0.37 \\
p<0.05\end{array}$ & $\begin{array}{l}r=0.375 \\
p<0.01\end{array}$ & $\begin{array}{l}r=0.085 \\
p=0.5651\end{array}$ \\
\hline WBC & $\begin{array}{l}r=0.231 \\
\mathrm{p}=0.152\end{array}$ & $\begin{array}{l}r=0.461 \\
p<0.001\end{array}$ & $\begin{array}{l}r=0.054 \\
p=0.7042\end{array}$ \\
\hline CRP & $\begin{array}{l}r=0.014 \\
p=0.932\end{array}$ & $\begin{array}{l}r=0.218 \\
p=0.1403\end{array}$ & $\begin{array}{l}r=0.108 \\
p=0.4716\end{array}$ \\
\hline hHGF & $\begin{array}{l}r=0.245 \\
p=0.2493\end{array}$ & $\begin{array}{l}r=0.766 \\
p<0.001\end{array}$ & $\begin{array}{l}r=0.045 \\
p=0.811\end{array}$ \\
\hline
\end{tabular}

STNFR と肝機能検查值および血液凝固検査值との 相関では，PT，HPT とは負の相関を，GOT，GPT，
WBC，hHGF，FDP とは有意の正の相関を認めた (Table 2).また,TNF- $\alpha$ およびICAM-1との間には 有意の正の相関を認めた。

\section{3. 血清 SICAM-1}

各疾患群における入院時の血清 SICAM-1は, AH $1,055.9 \pm 599.8(\mathrm{ng} / \mathrm{m} l)$, AHS $1,418.9 \pm 1,184.6$, FHA 1,834.4 $\pm 1,694$, FHS 1,906.8 \pm 662.6 , LOHF $2,185.4 \pm 534.7$ であり,健常者の184.8 336.5 に比して 有意の高値を示した (Fig. 4).

入院時と入院後を比較すると, 各疾患とも入院後に 低下を示し，とくに AH，FHA およびFHSでは有意 であった。しかし，生存例と死亡例との間での変動に は差異を認めなかった（Fig. 4，5).

肝機能検査值および血液凝固検査值との相関では, T. Bil とは有意の正の相関を, PT, HPT, AT-III と は有意の負の相関を認めた（Table 2)。また，血清 sTNFR との間には有意の正の相関を認めた。血清卜 ランスアミナーゼとの相関では入院時のみの検討では 相関を認めなかったが，血清トランスアミナーゼの低 下した入院後を含めるとGOT とは正の相関傾向 $(\mathrm{p}=$ 0.064) を, GPT とは有意の正の相関 $(\mathrm{p}<0.05)$ が認 められた。

\section{考察}

TNF- $\alpha$ はおもにマクロファージ・単球系の細胞か ら産生され, 腫場壊死活性, IL-1の産生促進, 抗ウイル ス作用など極めて多彩な生物活性を有している7n. 臨

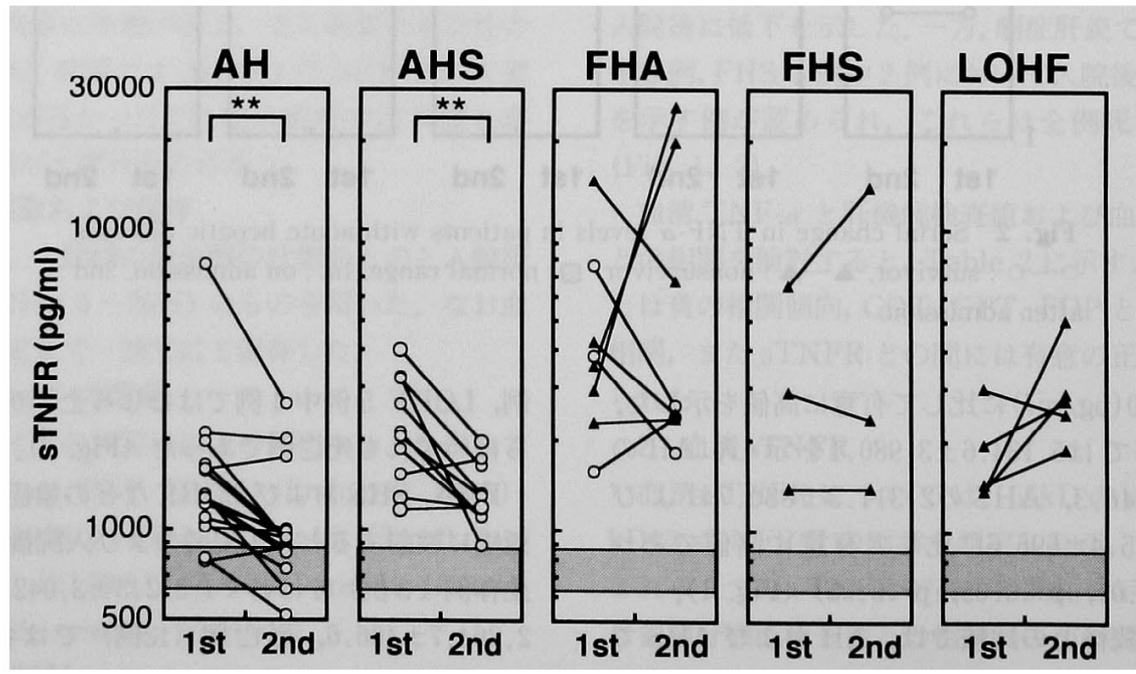

Fig. 3 Serial change in sTNFR levels in patients with acute hepatic diseases.

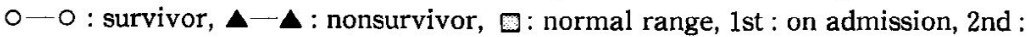
after admission. ${ }^{* *}: \mathrm{p}<0.01$. 


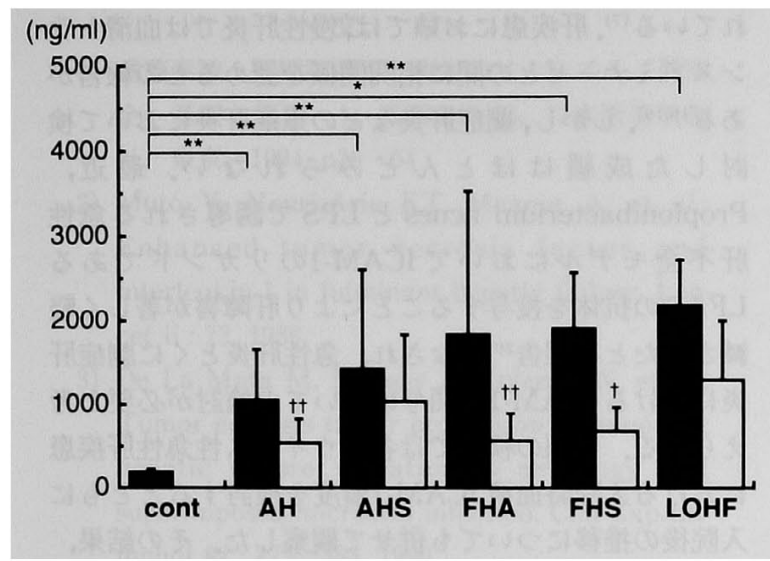

ICAM-1

Fig. 4 Serum levels of sICAM-1 in patients with acute hepatic disease on ( $\square$ ) and after ( $\square$ ) admission.

cont : healthy control, AH : acute hepatitis, AHS : acute hepatitis severe form, FHA : fulminant hepatitis acute form, FHS : fulminant hepatitis subacute form, LOHF : late onset hepatic failure. $*$ : $p<0.05,{ }^{* *}: p<0.01$ compared with level of control. $\dagger: p<0.05$, $\dagger^{\dagger}: \mathrm{p}<0.01$ compared with levels on admission.

床的には血清中の TNF- $\alpha$ 值は種々の感染性疾患で著 明な高值を示し, 炎症時の病態に関連していると考え られている。肝疾患においても急性肝不全例では血清 TNF- $\alpha$ の上昇をみるとの報告 ${ }^{3,8-11)}$ がみられ, さらに
急性肝不全例の未梢血単核球の TNF· $\alpha$ 産生が亢進し

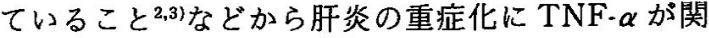
連していると考えられている，実験的には，D-ガラク トサミンと lipopolysaccharide (LPS) 併用投与に よって誘導される急性肝不全モデルにおいてLPSに 代わって TNF. $\alpha$ を投与すると同様な肝壊死を引き起 こすが，TNF- $\alpha$ 単独では肝障害を惹起しないことが 報告されている12).しかしながら，急性肝不全における 血清 TNF- $\alpha$ の上昇はグラム陽性菌や真菌感染症の存 在により左右されるとの報告”もあり，急性肝不全に おける血清 TNF- $\alpha$ の動態については必ずしも意見の 一致をみない。この一因として血清中に存在する TNF- $\alpha$ が極めて微量であることあるいは血清中に可 溶性 TNF- $\alpha$ 受容体（STNFR） ${ }^{4,5}$ )が存在しており, TNF- $\alpha$ と sTNFR が結合して複合体を形成している ことなどが考えられる.最近, sTNFR がTNF の中和 活性を有する ${ }^{5}$ と同時に slow release reservoir とし て作用する可能性 ${ }^{13)}$ も指摘され，肝炎の進展と終息に 関与している可能性があり,その動態が注目されてい る.

以上のことを踏まえ，今回，急性ウイルス性肝疾患 について血清中の TNF- $\alpha$ と STNFR を同時に測定 し, 入院時と入院後の推移よりその臨床的意義を明ら かにすることを目的として検討した。 その結果, 成績 で示したように血清 TNF- $\alpha$ と STNFR との間には有 意の相関関係があり, 両者はほほ同様の変動を示した が, sTNFR の方が PT, HPT, hHGF など肝炎の重

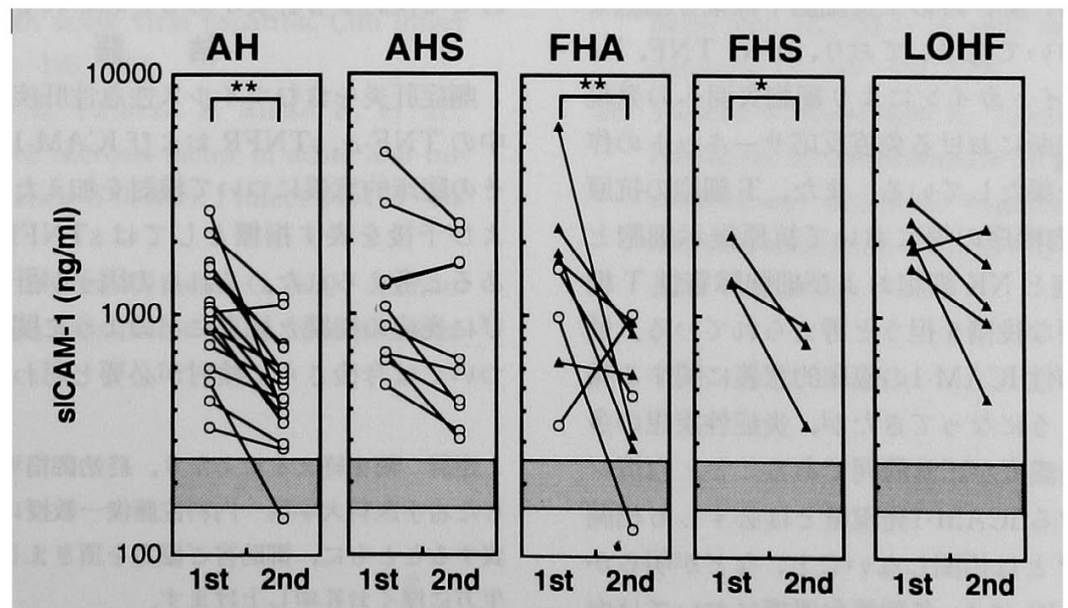

Fig. 5 Serial change in sICAM-1 levels in patients with acute hepatic diseases. $0-0$ : survivor, $\boldsymbol{\Delta}-\mathbf{\Delta}$ : nonsurvivor, $\square$ : normal range, 1st : on admission, 2nd : after admission. ${ }^{*}: p<0.05,{ }^{* *}: p<0.01$. 
$26: 654$

旰

症化を示す指標とより高い相関を認めることから, 劇 症肝炎においては TNF- $\alpha$ よりも鋭敏なマーカーとな りうることが推定された. また入院時と入院後とを比 較すると, 劇症肝炎, 覀急性肝炎, LOHF などにおい て血清中 STNFR 濃度の高值持続がみられ，とくに死 亡例においてはさらに上昇を示す例がみられることか ら, 予後の判定に有用である可能性が示唆された。

山下ら ${ }^{14)}$ は急性肝不全において血清中 sTNFR 濃度 は高值を示すものの急性肝炎との間には有意差を認め ず,また Tilg ら ${ }^{15)}$ 同様の成績を報告している。一方, 我々の成績では急性肝炎と劇症肝炎急性型との間に有 意差を認めたが，これは急性肝疾患の成因をウイルス 性に限定し，アルコール，薬剤性抢よび自己免疫性と 考えられる症例を除いて検討したことによると考えら れる. 我々の結果は De La Mata らのウイルス性急性 肝不全においては TNF- $\alpha$ の産生が LPS 刺激の有無 に関わらず進しているのに対して，パラセタモール 肝障害ではその現象がみられないとする成績賞あるい は Devictor らの実験肝障害においてパラセタモール 誘発肝障害では血中の TNF- $\alpha$ が上昇を示さないのに 対して, coronavirus (MHV-III) 誘発肝障害では有意

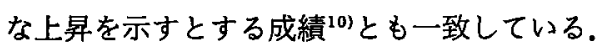

血清中の TNF- $\alpha$ およよ゙ sTNFR の上昇は単に肝細 胞破壊を反映したものではなく，肝局所で生じている 炎症反応とその程度を反映したものとして捉えること ができると考えられる。

ICAM-1は細胞間接着因子のひとつであり，血管内 皮細胞, マクロファージなどの抗原提示細胞のみなら ず消化管, 肝, 腎, 肺, 脾の上皮細胞や線維芽細胞な ど種々の組織において発現しており, IFN, TNF, IL1などの炎症性サイトカインにより細胞表面への発現 が増強し, 炎症局所における免疫反応サーキットの作 動に重要な役割を果たしている。また， T 細胞の抗原 認識扔よび殺細胞機序の場において抗原提示細胞と $\mathrm{T}$ 細胞, 標的細胞と NK 細胞および細胞障害性 $\mathrm{T}$ 細 胞との接着に重要な役割を担うと考えられている. 最 近, 血清中の可溶性 ICAM-1の臨床的意義に関する報 告が散見されるようになってきたが，炎症性疾患の多 くは血清 ICAM-1濃度が正常範囲であること, 血清レ ベルと組織におけるICAM-1発現量とは必ずしも相関 しないこと，CRP とは相関しないこと，などが明らか にされてきている16).また,各種消化器癌においては血 清 ICAM-1濃度は高值で，とくに進行例や転移を示す 例で著しいことより, 癌の転移における役割が注目さ
36巻11号（1995）

れている ${ }^{17)}$. 肝疾患においては, 慢性肝炎では血清トラ ンスアミナーゼとの間に相関関係を認めるとの報告が ある ${ }^{18.19)}$. しかし, 劇症肝炎などの重症肝炎において検 討した成績はほとんどみられない。最近， Propionibacterium acnes とLPSで誘導される急性 肝不全モデルに扔いて ICAM-1のリガンドである LFA-1の抗体を投与することにより肝障害が著しく軽

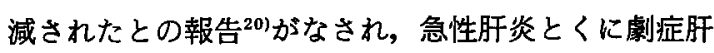
炎におけるICAM-1の関与についての検討が必要と考 えられる.今回の検討では各種ウイルス性急性肝疾患 における入院時血清 ICAM-1濃度を検討するとともに 入院後の推移についても併せて観察した. その結果, 各種ウイルス性急性肝疾患ではいずれの疾患において も健常者に比して有意に高値であり，FHA や LOHF では AH に比し有意の高值を示した。しかし，AHS， 劇症肝炎, LOHF の間には明らかな差は認められな かった。 また，入院時と入院後との比較では，いずれ の疾患においても入院後低下傾向を示し,とくに AH, FHA およびFHSでは有意に低下した.ささらに, 生存 例と死亡例での変動に差は認められず，予後との関連 は明らかではなかった。

血清 ICAM-1は, 血清 TNF- $\alpha$ や sTNFR と同様に 炎症の程度とともに肝炎の重症度を反映しているもの と考えられたが，血清 TNF- $\alpha$ や STNFR とは異なっ た挙動を示していた. 免疫反応に関わる細胞接着因子 においてはICAM-1を介さない経路も考えられてお り，その臨床的意義を明らかにするためには他の細胞 接着因子の測定とともに肝組織における発現状態をあ わせて検討する必要があると思われる.

\section{結語}

劇症肝炎を含むウイルス性急性肝疾患において血清 中の TNF- $\alpha$, STNFR および ICAM-1濃度を測定し, その臨床的意義について検討を加えた。肝の重症度お よび予後を表す指標としてはsTNFRが最も有用で あると考えられた．これらの因子が肝炎の重症化なら びに炎症の持続と終息にどのように関連しているかに ついては今後さらに検討が必要と思われる。

謝辞：稿を終えるにあたり，終始御指導御校閱を賜りま した岩手医科大学第一内科佐藤俊一教授に深甚なる謝意を 表するとともに, 御助言ご協力を頂きました研究室の諸先 生方に厚くお礼申し上げます。

なお, 本論文の要旨の一部は第29回日本肝臟学会東部会 および第31回日本肝臟学会総会にて発表した. 


\section{文献}

1）武藤泰敏：肝細胞壤死と再生のメカニズム.「肝不 全一基礎と臨床一」，武藤泰敏 編，日本医事新報 社, 東京, 1994, p26-64

2) Muto $Y$, Nouri-Aria KT, Meager A, et al: Enhanced tumor necrosis factor and interleukin-1 in fulminant hepatic failure. Lancet ii : 72,1988

3) De La Mata M, Meager A, Rolando $N$, et al : Tumor necrosis factor production in fulminant hepatic failure: Relation to aetiology and superimposed microbial infection. Clin Exp Immunol $82: 479-484,1990$

4) Olsson I, Mikael L, Nilsson E, et al : Isolation and characterlization of a tumor necrosis factor binding protein. Eur J Haematol $42: 270-$ 275,1989

5) Sekinger $P$, Isaaz $S$, Dayer JM : A human inhibitor of tumor necrosis factor $\alpha$. J Exp Med $167: 1511-1516,1988$

6）中舘一郎, 阿部弘一, 下遠野秀文, 他：急性肝炎, 劇症肝炎における血清可溶性 TNFレセプターの 測定. 肝臓 $36: 58-59,1995$

7）東 伸昭, 大沢利昭：腫瘄壊死因子.「現代科学増 刊18, サイトカイン一免疫応答および細胞の増殖, 分化因子」, 大沢利昭 編, 東京化学同人, 東京, 1990, p137-153

8) Torre D, Zeroli C, Giola $M$, et al: Serum levels of interleukin- $1 \alpha$, interleukin-1 $\beta$, interleukin-6, and tumor necrosis factor in patients with acute viral hepatitis. Clin Infect Dis $18: 194-198,1994$

9) Cacopardo B, Fatuzzo F, Russo R, et al : Serum tumor necrosis factor in acute and fulminant hepatitis B (letter). J Infect Dis 166 : 448 $-449,1992$

10) Devictor D, Decimo D, Sebire G, et al : Enhanced tumor necrosis factor alpha in coronavirus but not in paracetamol-induced acute hepatic necrosis in mice. Liver $12: 205-208,1992$

11) Zhang DF, Ren $H$, Jia XP, et al : Serum tumor necrosis factor (TNF) in the pathogenesis of clinical hepatic falure of $\mathrm{HCV}$ and/or $\mathrm{HBV}$ infection. Chin Med J 106 : 335-339, 1993

12）大西弘生, 森脇久隆, 名倉一夫, 他：劇症肝炎の発 症機序に関する実験的研究，とくに tumor necrosis factor (TNF) の役割について． 肝藏 30 : 103-104, 1989

13) Aderka D, Engelmann H, Maor $Y$, et al : Stabilization of bioactivity of tumor necrosis factor by its soluble receptors. J Exp Med 175 : 323-329, 1992

14）山下智省, 安永 満, 荁野幸三, 他：肝疾患におけ る血中可溶性 TNF- $\alpha$ レセプター (60kda) の測定 意義. 肝淢 $35: 331,1994$

15) Tilg H, Vogel W, Wiedermann CJ, et al : Circulation interleukin-1 and tumor necrosis factor antagonists in liver disease. Hepatology 18: $1132-1138,1993$

16）辻崎正幸, 今井浩三：可溶性 ICAM-1, VCAM-1。 医学のあゆ $169: 89-92,1994$

17）辻崎正幸, 今井浩三：覀性腫湯における接着分子. Biomedica $7: 377-381,1992$

18）銭谷幹男, 相沢良夫, 戸田剛太郎：慢性肝疾患にお ける血清中 intercellular adhesion molecule-1 (ICAM-1) について. 肝臟 $34: 64,1993$

19) Volpes R, Van Den Oord JJ, Desmet VJ : Hepatic expression of intercellular adhesion molecule-1 (ICAM-1) in viral hepatitis B. Hepatology 12 : 148-154, 1990

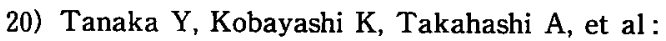
Inhibition of inflammatory liver injury by a monoclonal antibody against lymphocyte function-associated antigen-1. J Immunol 151 : $5088-5095,1993$ 


\title{
Serum levels of TNF- $\alpha$, TNF receptor and ICAM-1 in patients with acute and fulminant viral hepatitis
}

\author{
Ichiro NAKADATE, Koichi ABE, Yasuhiro TAKIKaWA and Kazuyuki SuzUKI*
}

We measured serum concentrations of TNF- $\alpha$, soluble TNF receptor (sTNFR) and soluble ICAM-1 (sICAM-1) in patients with acute hepatitis (AH), acute hepatitis severe form (AHS), fulminant hepatitis acute form (FHA), fulminant hepatitis subacute form (FHS) and late onset hepatic failure (LOHF). On admission, serum levels of TNF- $\alpha$, sTNFR and sICAM-1 were markedly elevated in patients with acute viral hepatitis. In particular, sTNFR in FHA was significantly increased compared with AH and AHS. The increases in TNF- $\alpha$, sTNFR and sICAM-1 were ameliorated following admission in AH and AHS, while deceased patients with FH or LOHF showed further increase in TNF- $\alpha$ and sTNFR. Significant correlations were observed between these markers and biochemical or coagulative data. We conclude that measurement of serum concentrations of TNF- $\alpha$, sTNFR and SICAM-1 is useful in predicting the prognostic feature of acute viral hepatitis.

* First Department of Internal Medicine, Iwate Medical University (Morioka) 